\title{
1969 年北海道東方沖地震の初期破壞過程
}

\author{
京都大学防災研究所 井 元 政 二 郎 \\ (昭和 50 年 12 月 17 日受理)
}

\section{On a Starting Point of the Large Fracture of August 11, 1969 Hokkaido Toho-oki Earthquake}

\author{
Masajiro Iмото \\ Disaster Prevention Research Institute, Kyoto University
}

(Received December 17, 1975)

In the study of the source process of an earthquake, it is important to know the position of the main shock relative to the aftershock area. The epicenters of the large earthquake on August 11, 1969 and several foreshocks in a minute before are determined by JMA (Japan Meteorological Agency), USCGS (U.S. Coast and Geodetic Survey) and ISC (International Seismological Center). But, different locations are derived from each determination to the aftershock area, and the apparent rupture velocity between the last foreshock and the main shock, calculated from the data of USCGS and ISC, is higher than $10 \mathrm{~km} / \mathrm{s}$. It is probable that the later phases due to the foreshocks disturb the initial arrival due to the main shock.

In the present paper, the locations of the main shock and foreshocks are determined precisely by simple least squares procedure. From precise locations, the main shock seems to start from a point on the landward edge of the aftershock area. This relation between the epicenter of the main shock and the aftershock area is similar to those of other earthquakes which occurred recently along the Kurile trench near Hokkaido. The apparent rupture velocity turns out to be about $3.2 \mathrm{~km} / \mathrm{s}$.

\section{§1. はじめに}

余震の発生機構，すなわち等価力源のモデル，エネルギー放出の時間的空間的性質などは， 多くの人によつて研究されて来た。これらの研究は, 震源過程の研究に重要な情報を与えてく れる. 例えば， circular crack の場合の破壊領域（余震域がよく使われる）と， seismic moment, stress drop との関係式はよく知られている [ESHELBY (1957); AKI (1966)]. また, 余震域を破壞領域と見なせば，本震位置は主破壞の始まつた点と考えられる．従つて，本震の 余震域に対する相対位置は, 断層面での破壊拡大の様子を最も簡潔に表わすと考えられる.

本震位置はその余震域の端にあることが多いとよくいわれる。このような地震では，破壊拡 大の様子が払大の方向によつて違うとも考兄られ。しかし，その仕組は明らかでない。この 
仕組を調べる方法として，例えば空間的に近接した発震機構の似ている大地震のそれぞれの余 震域に対する相対位置を比較する方法が考えられる。

ここでは，1969 年 8 月 11 日 21 時 27 分 (G.M.T.) 北海道東方沖地震の余震域に対する 相対位置について述べる.この地震については，余震，津波，表面波による解析など何人かの 人々 [本谷 (1970)；ABE (1973)] によつて，すでに研究がなされている。また，多数の前震が 発生していることも，よく知られている。しかし，この前震（特に一分前に発生した大きい前 震) に対する本震の相対位置，あるいは余震域に対する本震の相対位置は，気象庁，USCGS， ISC の各報告によりそれぞれ異なつている．また，USCGS と ISC の報告では，本震直前 10 秒ほどの間にも地震が発生していることになつて抢り，この前震と本震との間での apparent rupture velocity は, $10 \mathrm{~km} / \mathrm{sec}$ 以上にもなる。これは，他の multiple shocks の解析で得 られている速度よりかなり速い。

そこで，この地震をｉ）余震域に対する本震の相対位置 ii）本震の初期に护ける破壊の伝 播 に関する点から調べた。

\section{§2. 資料}

解析には，世界標準地震計観測網の長周期地震計，短周期地震計および気象庁 59 型直視式 電磁地震計による記録を使用した。 また，補助資料として気象庁，USCGS，ISC の各報告を 用いた. Table 1 に対象とした地震の震源, 発震時が示されている.

発震機構については，P 波初動の押し引き分布によると一つの節面しか定められず， $\mathrm{S}$ 波に よつてもその初動方向を求めるのが困難なため, Table 1 に示された地震はすべて本震と同じ

Table 1. The list of the earthquakes used in the present study given by JMA (a), CGS (b) and ISC (c). $M_{s}$ means surface wave magnitude.

\begin{tabular}{|c|c|c|c|c|c|c|c|c|}
\hline Source & No. & & $\operatorname{gin}_{M}$ & ime & Latitude & Longitude & $\underset{(\mathrm{km})}{\text { Depth }}$ & Magnitude \\
\hline \multirow{2}{*}{ (a) } & 1 & 21 & 26 & 32.6 & $43^{\circ} 6^{\prime}$ & $148^{\circ} 11^{\prime}$ & 50 & $\mathrm{R}$ \\
\hline & 2 & 21 & 27 & 39.1 & $42^{\circ} 32^{\prime}$ & $147^{\circ} 37^{\prime}$ & 30 & 7.8 \\
\hline \multirow{4}{*}{ (b) } & 1 & 21 & 26 & 37.6 & $43.4^{\circ}$ & $147.9^{\circ}$ & 43 & 5.7 \\
\hline & 2 & 21 & 27 & 25.8 & $43.6^{\circ}$ & $147.8^{\circ}$ & 14 & 5.9 \\
\hline & 3 & 21 & 27 & 36.0 & $43.5^{\circ}$ & $147.8^{\circ}$ & 45 & 6.2 \\
\hline & 4 & 21 & 27 & 39.4 & $43.5^{\circ}$ & $147.4^{\circ}$ & 28 & $7.8 M_{s}$ \\
\hline \multirow{4}{*}{ (c) } & 1 & 21 & 26 & 33.0 & $43.46^{\circ}$ & $147.9^{\circ}$ & 8 & 5.8 \\
\hline & 2 & 21 & 27 & 30.2 & $43.59^{\circ}$ & $147.63^{\circ}$ & 45 & 5.9 \\
\hline & 3 & 21 & 27 & 35.6 & $43.44^{\circ}$ & $137.82^{\circ}$ & 41 & 6.5 \\
\hline & 4 & 21 & 27 & 41.0 & $43.61^{\circ}$ & $147.18^{\circ}$ & 38 & 6.5 \\
\hline
\end{tabular}




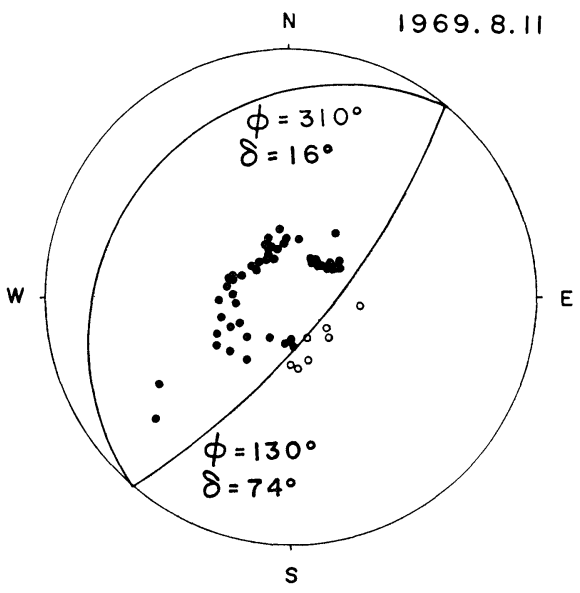

Fig. 1. Focal mechanism solution of the earthquake of Aug. 11, 1969. The radiation patterns of the first $P$ motions are projected onto the lower half of the focal sphere. Solid and open circles indicate the compressions and rarefactions respectively. The nodal planes are drawn according to $\mathrm{ABE}$ (1973).

発震機構をもつとした。ABE (1973) によ

ると，P 波の二つの節面は dip direction， dip angle がそれぞれ $\phi=31^{\circ}, \delta=16^{\circ}$ と $\phi=130^{\circ}, \delta=74^{\circ}$ となつている (Fig. 1 参 照).

気象庁，USCGS，ISC で決定された余 震の分布および Table 1 に表わされた地 震の震源位置が，Fig. 2(a), 2(b), 2(c) に 示されている.

\section{§3. 解析方法}

長周期地震計記録 (Table 1 亿表わされ た地震の $\mathrm{P}$ 波初動部分，拈よそ一分間の 記録）における観測点間での波形の関係を 調べる.

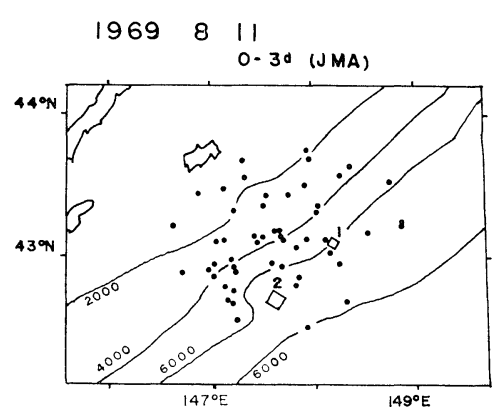

(a)

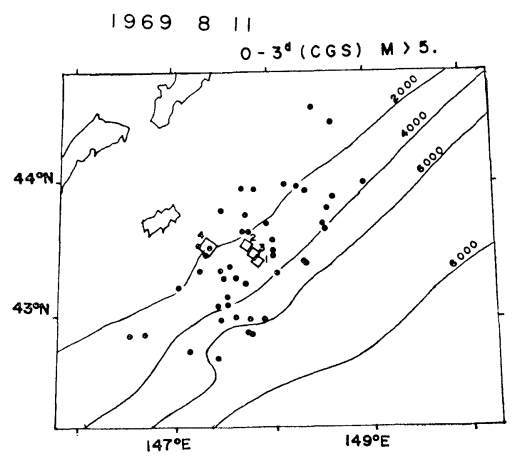

(b)

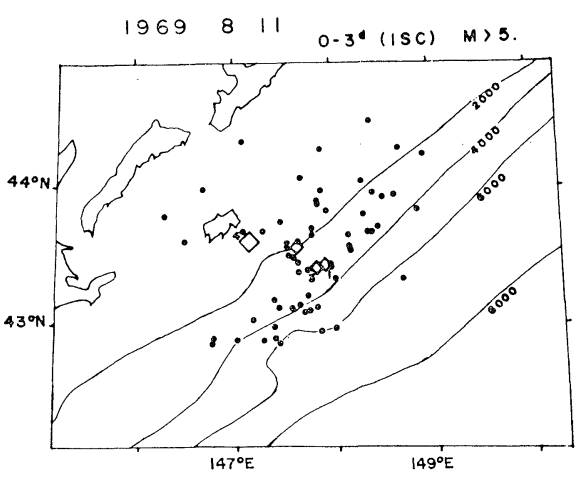

(c)

Fig. 2. The epicenters of the earthquakes listed in Table 1 (open squares), and the aftershocks during three days just after the main shock (closed circles). " $M>5$ " means epicenters of aftershocks with magnitude greater than 5 . 
LONG PERIOD

- AZIMUTH (DEG)

$\triangle$ EPICENTRAL DISTANCE (DEG)
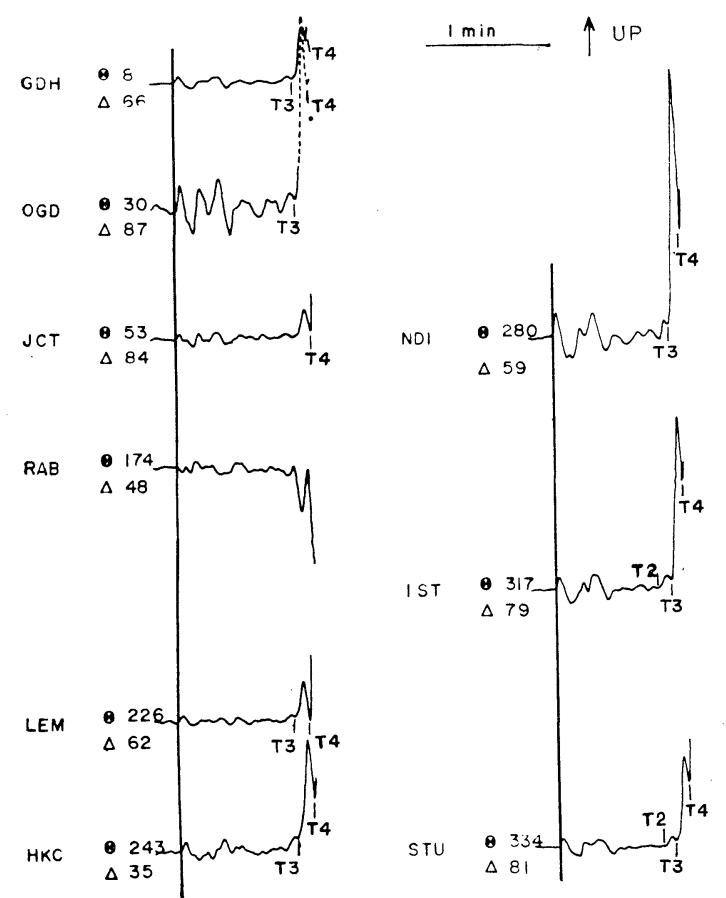

Fig. 3. Examples of long period seismograms. Vertical lines indicate the arrival time due to the earthquake No. 1 in Table $1(b)$.

Fig. 3 に長周期地震計上下動成分の記録が例示されている. 記録は, 地震 1 (Table 1(b) で No. 1 とした地震) の arrival timeを揃えて並べられている.この arrival time には同 一観測点の短周期地震計の記録から読取つた值を用いて掞り，精度はよいと考えられる。また， Fig. 4 には同じく短周期地震計上下動成分の記録が示されている. Fig. 3 では，0. 秒（地震 1 の arrival time) から 25 秒の約 25 秒間と, 50 秒以後とに执いて各観測点の波形が似ている. しかし，Fig. 4 からわかるように，短周期記録では長周期記録ほどには観測点間での波形の 対応がよくない，従つて，短周期記録による波群の分離判定は適当でないよらである.

そこで, 長周期地震計上下動成分の記録波形の山, 谷の時刻を可能な限り読取り, この值 (地震の初動との発現時刻の差) を中心にして, 解析を進める. Fig. 5(a) に初動の arrival time を基準とする各波の arrival time と震央距離との関係が示され，Fig. 5(b) には観測点 の方位との関係が示されている，黒丸，白丸はそれぞれ波の山，谷を示し，読取り精度がよい と考えられるものほど大きく表わされている，これらの図からも，0 秒から 25 秒の約 25 秒 
間と 50 秒以後の波形がよく似ているこ とは確かめられる。この 50 秒以後の部 分に対して，山を $\mathbf{P}$ 谷を $\mathbf{T}$ とし順に T2, P2， T3， P3，T4 とする.

I) Event 1 について

0 秒から 25 秒までは，震央距離に対 しても, 方位角に対しても, 読取り值は 同じ程度のばらつき方をしており, 地震 は一つしか発生していないようである (Fig. 5(a)，5(b) 参照). 8 秒ぐらいに現 われている phase (Fig.5(a), 5(b) では 白丸で表わされている phase）も，多く の点で観測されて挆り， Fig. 5(a) と Fig. 5(b) ではやはり同じ程度のばらつ きを示している。また， $\mathrm{P}$ 波節面近くの 観測点に扣いても, 初動半周期の小振巾 に比べ，この phase は明瞭である. 従 つて，この phase は直達 $\mathrm{P}$ 波によるも のではなく, pP 波等の二次的な波によ ると考兄れる. Fig. 6 で, 地震 1 と 余震の記録の 0 秒から 25 秒をでを比較 すると，波形に大きな違いはない。これ は，この間に地震 1 の震源で発生した波（event 1) は，Fig. 6 に示した余震と同様に単純な ものであつたが，記録波形がやや複雑なのは震源近やで派生した二次的な波によるためだと考 えられる。

\section{II) 25 秒から 50 秒まで}

25 秒から 50 秒までは，読取り可能な phase が少なく観測点によりかなり異なつている. ここでは，波群の判定はできない。

III) event 2, 3, 4 の initial arrival について

50 秒以後（およそ 70 秒まで）に执いて，長周期記録（Fig. 3 参照）では, 波形の対応は よい。また，短周期記録では抢よそ 52 秒のところから event 1 と同程度の振幅の波が見られ 

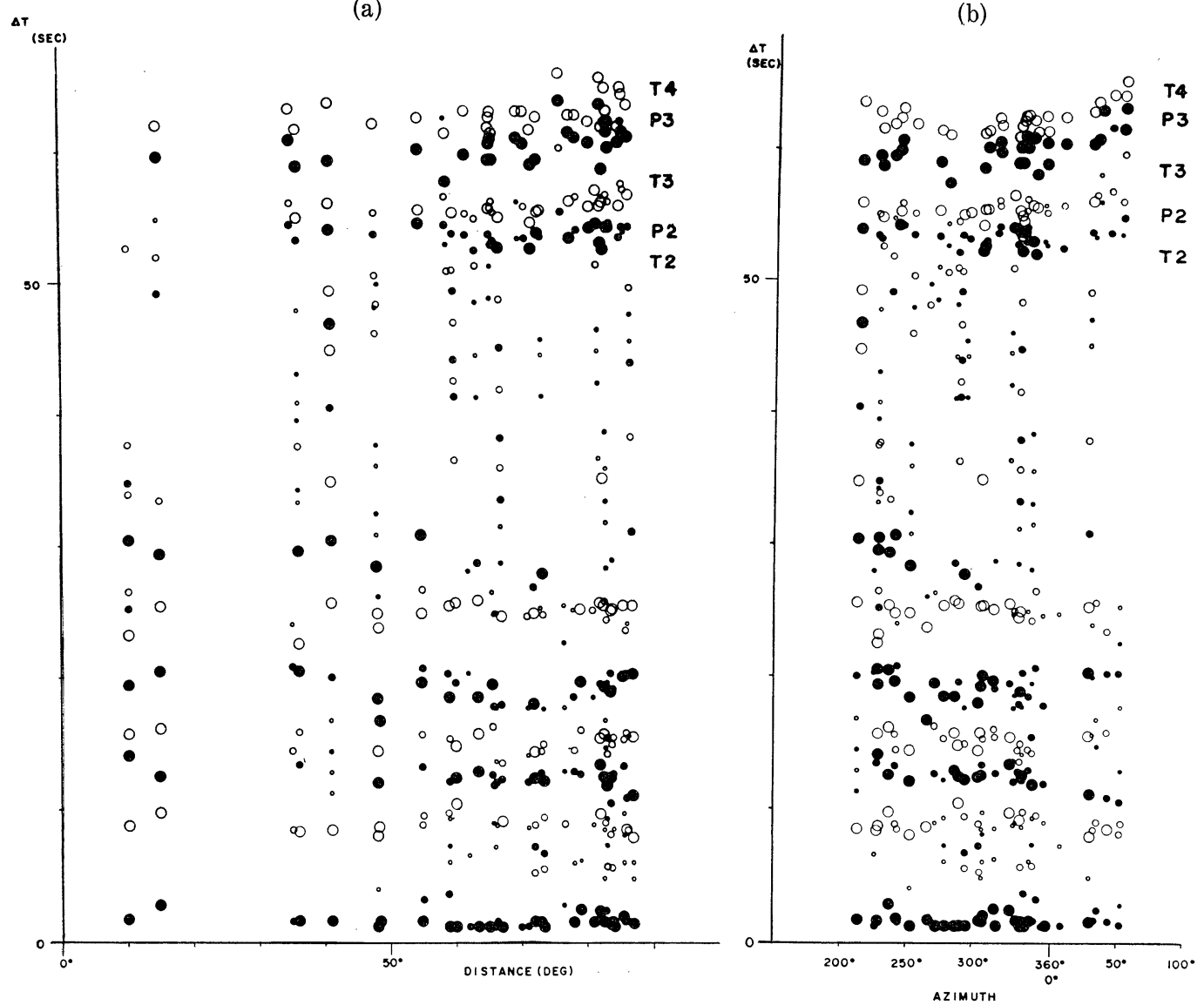

Fig. 5. Plots of the time differences between the initial arrival and later arrivals for event 1 against epicentral distance (a) and azimuth (b). As for T2, P2, etc, see the text.

る.これが続発した地震 (event 2) の初動だと考えられるが，精度よく読取れる観測点はあ まり多くない。より大きい振幅の波群が引続いて現われているが，観測点間での対応は明らか でない.

Fig. 7 に，P, pP, sP 波の初動方向が遠方の観測点について示されている，P 波の押し引 きは Fig. 1 に従つた. pP, sP 波の初動の向きは，次の仮定をして Fig. 1 の発震機構から算 出した，a）地表面への入射角は震源での射出角 (上方からはかつた角度) に等しいとし，入反 射の関係は，Poisson's ratio $\sigma=0.25$ の媒質として計算した．b) 反射波の初動方向は，a）で 求めた反射角と等しい射出角をもつ $\mathrm{P}$ 波の投影点に重ねて表示した，図中，曲線は各波の節 線を示しており，これらの節線で囲まれたそれぞれの部分に，そこで期待される $\mathrm{P}, \mathrm{pP}, \mathrm{sP}$ 波の初動方向が順に十（地動上向き）または一（地動下向き）で示されている。また，黒丸は 


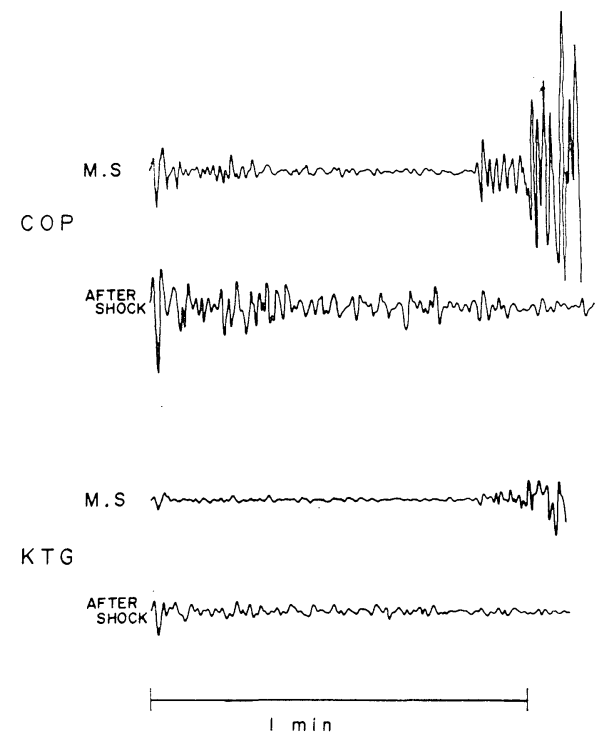

Fig. 6. Examples of short period seismograms of an aftershock in comparison to the main shock.

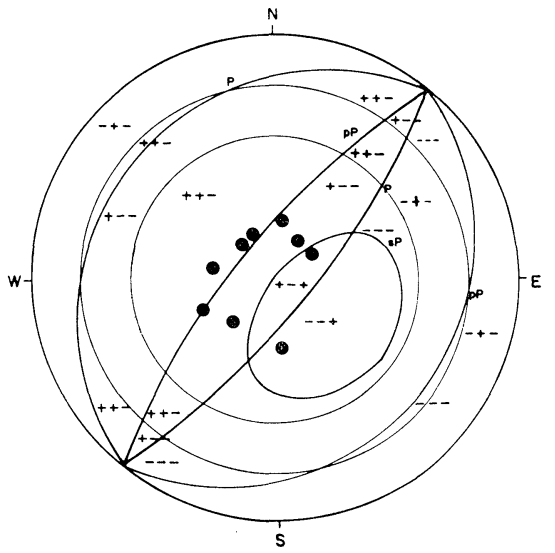

Fig. 7. Nodal curves of $\mathrm{P}, \mathrm{pP}$ and $\mathrm{sP}$ waves and distribution of the stations (solid circles) quoted in Fig. 3. Series of signs indicate the polarities of $\mathrm{P}, \mathrm{pP}$ and $\mathrm{sP}$ phases. + and - signs indicate compressions and rarefactions respectively.

Fig. 3 に例示された観測点の位置を表わしている.これらの観測点は $\mathrm{pP}$ 波と $\mathrm{sP}$ 波の節線 の両測に配置している。もし T2，P2，T3，P3，T4 のどれかが $\mathrm{pP}$ 波や $\mathrm{sP}$ 波の到達による ものであれば， $\mathrm{pP}$ 波や $\mathrm{sP}$ 波の節線の両側でこれらの波の初動方向が逆になるために，そこ で波形はかなり異なるであろう。しかし，Fig. 3 に示されているように，pP 波や $\mathrm{sP}$ 波の節 線の両側にある観測点間でも波形はよく似ている．従つて，T2, P2, T3, P3, T4 は pP 波や sP 波によるものではなく直達 P 波によるものと考えられる．このことは，Fig.5 (a)に比べ Fig. 5(b) の方が丸のばらつきが少ないことからもわかる．ここで，T2，T3，T4を event 2, 3, 4 の initial arrivals と見なしてよかろう.

IV) Multiple shocks としての解析

次に, event $1 \sim 4$ の震源位置を求める.

Event 1 に対して event $i(i=2,3,4)$ が離れた点 $\left(\Delta X_{i}, \Delta Y_{i}, \Delta Z_{i}\right)$ で $\tau_{i}$ 遅れて発生したと する. 第 $j$ 番目の観測点に抢いて観測される二つの event の発現時刻の差 $\Delta T_{i j}$ は, 次式で 表わされる.

$$
\begin{aligned}
\Delta T_{i j} & =\tau_{i}-\left(\Delta X_{i} a_{x j}+\Delta Y_{i} a_{y j}+\Delta Z_{i} a_{z j}\right) / V_{p} \\
1 & =a_{x j}^{2}+a_{y j}^{2}+a_{z j}^{2}
\end{aligned}
$$

ここで， $\tau_{i}$ は event $i$ と event 1 との発生時刻の差であり, $\left(\Delta X_{i}, \Delta Y_{i}, \Delta Z_{i}\right)$ は event 1 
Table 2. The result of the analysis of multiple events. Each number in round brakets indicates the value of the standard deviation. Directions of $\Delta X, \Delta Y$ and $\Delta Z$ are taken to be eastward, northward and upward respectively.

\begin{tabular}{|c|c|c|c|c|c|}
\hline Event & $\Delta X(\mathrm{~km})$ & $\Delta Y(\mathrm{~km})$ & $\Delta Z(\mathrm{~km})$ & $\tau(\mathrm{sec})$ & S.D.(sec) \\
\hline 1 & 0. & 0. & 0. & 0 . & \\
\hline 2 & $\begin{array}{c}-9.0 \\
(4.4)\end{array}$ & $\begin{array}{c}13.8 \\
(4.3)\end{array}$ & $\begin{array}{c}1.7 \\
(12.6)\end{array}$ & $\begin{array}{l}52.2 \\
(1.4)\end{array}$ & 0.6 \\
\hline 3 & $\begin{array}{r}-19.4 \\
(4.1)\end{array}$ & $\begin{array}{c}5.4 \\
(3.7)\end{array}$ & $\begin{array}{c}0.7 \\
(10.6)\end{array}$ & $\begin{array}{l}56.3 \\
(1.2)\end{array}$ & 0.5 \\
\hline 4 & $\begin{array}{r}-40.6 \\
(4.4)\end{array}$ & $\begin{array}{l}20.2 \\
(4.4)\end{array}$ & $\begin{array}{c}-13.0 \\
(12.5)\end{array}$ & $\begin{array}{c}65.4 \\
(1.4)\end{array}$ & 0.6 \\
\hline
\end{tabular}

の震源を原点とする座標系での event $i$ の座標成分であり, $\left(a_{x j}, a_{y j}, a_{z j}\right)$ は同じ座標系で event 1 から観測点 $j$ に向う震波線の方向余弦である。また， $V_{p}$ は原点近傍に抢ける $\mathrm{P}$ 波 速度である. 式 (1) により, 最小二乗法で $\tau_{i}, \Delta X_{i}, \Delta Y_{i} \Delta Z_{i}$ が簡単に求まる [ISACKS et al. (1967); OIKE (1969)].

計算結果が Table 2 に示されている. $\Delta X, \Delta Y, \Delta Z$ の向きは, それぞれ東, 北, 上向きで ある. S.D. は最小二乗法の標準偏差であり, 各座標成分の下には誤差の範团が示されている.

V) Event 1,2,3 の破壞領域の推定

球形成層構造において, 複双力源の点震源から放出された $\mathrm{P}$ 波の遠地での変位 $U(t)$ は, モ ーメント $M(t)$ を用いて, 次のように表わされる [HONDA (1962)].

$$
\begin{aligned}
U(t) & =\frac{R_{\theta} f \dot{M}(t)}{4 \pi \rho_{h} v_{h}{ }^{3}}, \\
f & =\frac{1}{r} \sqrt{\frac{\rho_{h} v_{h} \sin i_{h}}{\rho_{0} v_{0} \sin \Delta \cos i_{0}}\left|\frac{d i_{h}}{d i}\right|}
\end{aligned}
$$

ここに, $R_{\theta}: P$ 波 Radiation pattern の効果, $\Delta:$ 震央距離, $i_{h}$ : 射出角, $i_{0}$ : 観測点での入 射角であり, $v_{0}=v_{h}=8.0 \mathrm{~km} / \mathrm{sec}, \rho_{0}=\rho_{h}=3.3 \mathrm{~g} / \mathrm{cm}^{3}, r=6400 \mathrm{~km}$ とした。

地震の波形を調べるには，さらに a) マントル内の非弾性的性質による波形の変化，b）地 殸構造および地表で観測していることによる波形の変化，を考える必要がある.

a) マントルに打ける減衰

非弾性的性質による減衰の周波数特性は, $\exp [-\omega T /(2 \bar{Q})]$ で表わされる [MIKUMO (1969)]. $\omega$ は対象とする波の角周波数， $T$ は走時， $\bar{Q}$ はその波の通過した経路での平均的な值である. 震央距離が $40^{\circ}$ から $80^{\circ}$ で周期が 5 秒の $\mathrm{P}$ 波では， $T / \bar{Q}=1.1 \sim 1.6$ である [MIKUMO (1975)]. この值を代入すると, $\exp [-\omega T /(2 \bar{Q})]=3.75 \sim 0.50$ となる. 
b) 地壳による影響

周期 5 秒の $\mathrm{P}$ 波が地殼へ 20 度ないし 30 度の角度で入射すると, 地表では振幅が 2 倍な いし 3 倍になつた波が観測される [HASKELL (1962); MIKUMO (1969)].

従つて，a）b）による波形の変化は，周期 5 秒の $\mathrm{P}$ 波については振幅が 0.7 倍ないし 1.5 倍になる.一方, event 1, 2, 3 における見かけの初動半周期は 4 秒ないし 7 秒である。こ こでは， $\dot{M}(t)$ として event $1,2,3$ ともに 5 秒間の矩形波を仮定した [BOLLINGER (1968); MikUMo (1971)]. 式 (2) による $U(t)$ に地震計の応答を考慮したものを理論波形とした。この 波形の振幅と，観測された波形の振幅とを比較し，各観測点でモーメントを求める。これを平 均して event に対するモーメントとした。各 eventに対するモーメントを $M_{i}(i=1,2,3,4)$ で表わすと， $M_{1}=M_{2}=3.6 \times 10^{25}(\mathrm{dyne} \cdot \mathrm{cm}), M_{3}=3.3 \times 10^{26}(\mathrm{dyne} \cdot \mathrm{cm})$ となる. Event 4 に対 して, $M_{4}=2.2 \times 10^{28}($ dyne $\cdot \mathrm{cm})$, 破壊領域: $S_{4}=85 \times 180\left(\mathrm{~km}^{2}\right)$ が既に得られている [ABE (1973)].

次の式は, circular crack における $\Delta \sigma$ : stress drop, $M$ : seismic moment, $S$ : 破壊領域 の間の関係式としてよく知られている [ESHELBY (1957); AKI (1966)].

$$
\Delta \sigma=\frac{7 \pi^{3 / 2}}{16} \frac{M}{S^{3 / 2}} .
$$

さらに,これら 4 つの events において, stress drop が等しい「AKI (1972)] とすれば, 式（3）から次式が導かれる.

$$
\frac{M_{i}}{M_{i}}=\left(\frac{S_{i}}{S_{j}}\right)^{3 / 2}, \quad(i, j=1,2,3,4) .
$$

これに，既知の $S_{4}, M_{i}(i=1,2,3,4)$ を代入 して, $S_{i}(i=1,2,3)$ を得る。結果が Table 3 に示されている.

§4. 考察

I) Event 2, 3, 4 について

Table 2 に示された events $2,3,4$ の震源と USCGS で決定された余震の震源 (Fig. 2(b) 参照) とが，Fig. 8(a) に重ねて図示されている，基準とした event 1 の震源として，震央は USCGS の報告值を用い，深さは $\mathrm{pP}$ 波によると $15 \mathrm{~km}$ から $25 \mathrm{~km}$ と考えられるので $20 \mathrm{~km}$ とした，図で，events 1,2,3 を中心とした円は，各 event の破壊領域が円形の場合の大きさ を示している。 また， $\mathrm{N} 50^{\circ} \mathrm{W}$ 方向の垂直断面に投影した events $1,2,3,4$ の位置とその誤差 area for each event. The parameters for the event 4 are after ABE (1973).

\begin{tabular}{c|c|c}
\hline Event & $S\left(\mathrm{~km}^{2}\right)$ & $M($ dyne $\cdot \mathrm{cm})$ \\
\hline 1 & $2.1 \times 10^{2}$ & $3.6 \times 10^{25}$ \\
2 & $2.1 \times 10^{2}$ & $3.6 \times 10^{25}$ \\
3 & $9.3 \times 10^{2}$ & $3.3 \times 10^{26}$ \\
4 & $1.53 \times 10^{4}$ & $2.2 \times 10^{28}$ \\
\hline
\end{tabular}

Table 3. Each seismic moment and fracture 


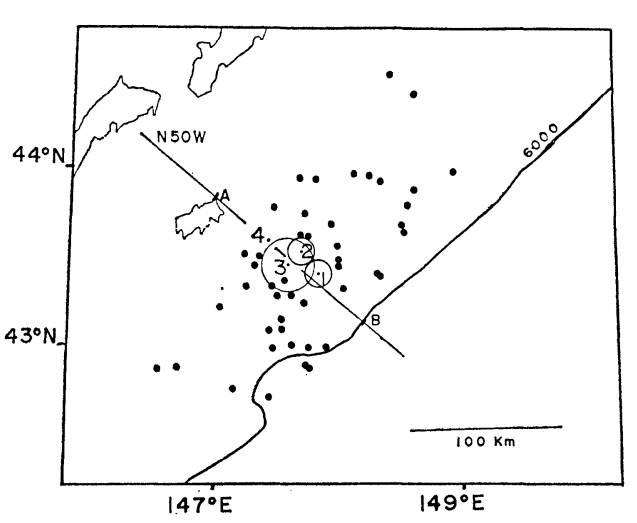

(a)

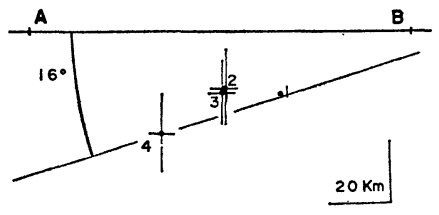

(b)

Fig. 8. (a) The locations of the four events given by Table 2 and epicenters of aftershocks plotted in Fig. 2(b).

(b) Projection of the four foci on the vertical cross section, which is taken along $\mathrm{AB}$ line in Fig. 8(a).
の範囲とが，Fig. 8(b) に示されている. Fig. 8(a) で, events 3，4 はそれぞれ events 2, 3 の破壊領域の端に位置して おり，破壊が $2,3,4$ と伝播したと考光得 る。それらの間での apparent rupture velocity を求めると， $\quad 3.2 \sim 3.4 \mathrm{~km} / \mathrm{sec}$ となる. Table 1 に示されている報告值 から計算される值 $(10 \mathrm{~km} / \mathrm{sec}$ 以上) よ りもこの值の方が，すでに得られている 值 [OIKE (1967, 1971); FUKAO (1972); CHANDRA (1973)] とよい一致を示す。さ らに, 表面波の解析で得られた rupture velocity $3.8 \mathrm{~km} / \mathrm{sec}$ [ABE (1973)] とも よく調和する。

II) 気象庁の本震位置

気象庁の報告による地震 1 と地震 2 (本震) との位置関係は, 解析結果の event 1 に対する events 2,3,4 のいず

れの位置関係とも一致していない。これは, 本震として報告された読取り值が, 計器の周波数 特性の違いなどにより，波形の上で異なる部分を示しているために生じたと思われる.

III）周辺の地震との比較

この地震の震源近くで, 最近発生した大地震の震源, 発震時が, Table 4 に表わされている. これらの地震の震源と余震域とが Fig. 9 に示されている. 図の本震位置から, この地域に

Table 4. List of the large earthquakes which occurred recently along the Kurile trench near Hokkaido (from the data of CGS).

\begin{tabular}{|c|c|c|c|c|c|c|c|c|}
\hline \multirow{2}{*}{\multicolumn{3}{|c|}{ Date }} & \multirow{2}{*}{\multicolumn{3}{|c|}{$\underset{H}{\text { Origin Time }}{ }_{M}^{\text {(G.M.T.) }}$}} & \multirow{2}{*}{\multicolumn{2}{|c|}{$\begin{array}{l}\text { Epicenter } \\
\text { Latitude } \quad \text { Longitude }\end{array}$}} & \multirow{3}{*}{$\frac{\begin{array}{c}\text { Depth } \\
(\mathrm{km})\end{array}}{45}$} \\
\hline & & & & & & & & \\
\hline 1952 & 3 & 4 & 01 & 22 & 41. & $42.5^{\circ}$ & $143.5^{\circ}$ & \\
\hline 1958 & 11 & 6 & 22 & 58 & 06. & $44.5^{\circ}$ & $148.5^{\circ}$ & 80 \\
\hline 1963 & 10 & 13 & 05 & 17 & 57. & $44.8^{\circ}$ & $149.5^{\circ}$ & 40 \\
\hline 1968 & 1 & 29 & 10 & 19 & 05.6 & $43.6^{\circ}$ & $146.7^{\circ}$ & 40 \\
\hline 1973 & 6 & 17 & 03 & 55 & 02.9 & $43.2^{\circ}$ & $145.8^{\circ}$ & 48 \\
\hline
\end{tabular}




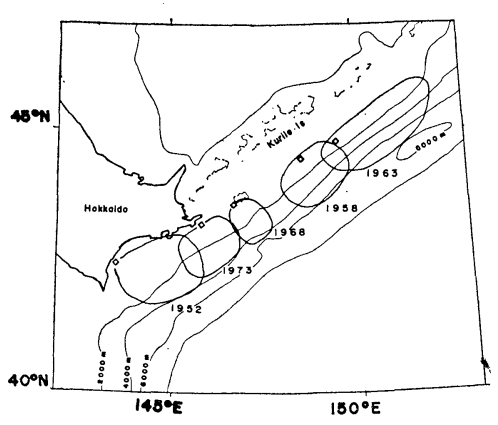

(a)

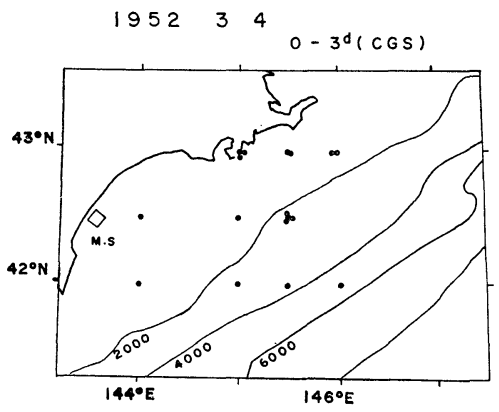

(b)

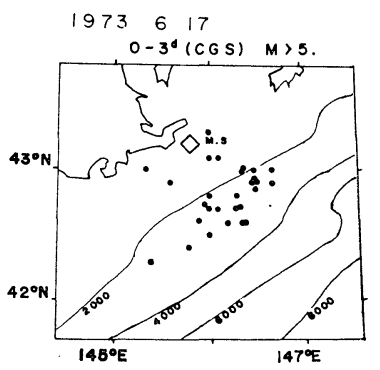

(c)

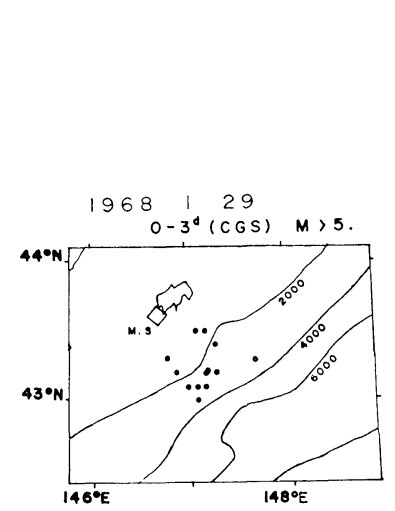

(d)

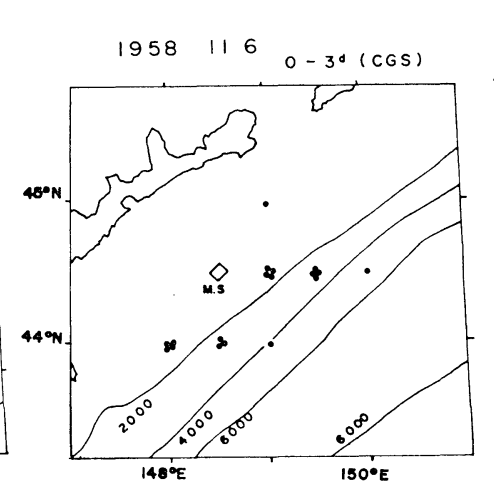

(e)

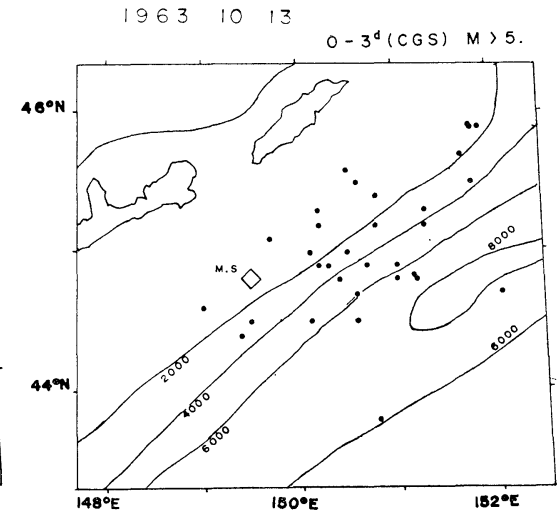

(f)

Fig. 9. (a) The epicenters in Table 4. and their aftershock areas. (b)-(f) Each main shock (open square) and its aftershocks during three days just after the main shock. " $M>5$ " means epicenters of aftershocks with magnitude greater than 5 .

おける大地震は，その余震域の最も陸に近い端から破壊を始めていることがわかる，ここで解 析した地震も， event 4 を主破壞の始まりだとすれば，同様な破壞様式であると考学られる. このような現象については，KELLHER et al. (1973) によつて既に調べられている。それによ ると，海溝に発生する低角逆断層型大地震において，破壊は陸側で始まり断層面上を海溝の方 へ広がる。このようにその始まり位置が陸側に片寄るのは，破壞が応力の状態によることを考 慮すれば，地震発生前において歪の蓄積が一様でないためだと考劣られる。 KANAMORI and CIPAR (1974) は 1960 年のチリ地震を調べ, 本震の前に本震断層下方延長上で aseismic slip があつたとしている。このような slip の発生後その近傍では歪が一様でなく，本震発生前に 応力集中が本震断層面の陸側に生じてくることは十分考えられる．従つて，このような aseismic slip の現象が低角逆層型大地震に共通するものであれば，丕が非一様的に蓄兄られ る機構に対する一つの説明になると考えられる. 
謝 辞

この報告をまとめるに際して御指導いただいた岸本兆方教授，尾池和夫助教授，さらに多く の助言ならびに貴重な資料を使わせていただいた三雲健教授に御礼申し上げます。

また，観測資料を集めるにあたり，気象庁各気象台，各大学観測所の皆様にはたいへんお世 話になりました。

なお，計算には京都大学大型計算機センターおよび京都大学防災研究所防災科学資料センタ 一の電子計算機を使用しました。

文献

ABE, K., 1973, Tsunami and Mechanism of Great Earthquakes, Phys. Earth Planet. Interiors, 7, 143-153.

AKI, K., 1966, Generation and Propagation of G-Waves from the Niigata Earthquake Moment, Released Energy, and Stress-Strain Drop from the G-wave Spectrum, Bull. Earthq. Res. Inst., Tokyo Univ., 44, 73-88.

AKI, K., 1972, Earthquake Mechanism, Tectonophysics, 13, 423-446.

Bollinger, G. A., 1968, Determination of Earthquake Fault Parameters from Long-Period P Waves, J. Geophys. Res., 73, 785-807.

Chandra, U., 1973, Discussion: Source Process of a Large Deep-Focus Earthquake and its Tectonic Implications-The Western Brazil Earthquake of 1963: Comments, Phys. Earth. Planet. Interiors, 7, 115-121.

Eshelby, J.D., 1957, The Determination of the Elastic Field of an Ellipsoidal Inclusion and Related Problems, Proc. Roy. Soc., London, A241, 376-396.

FukAo, Y., 1972, Source Process of a Large Deep-Focus Earthquake and its Tectonic Implications-The Western Brazil Earthquake of 1963, Phys. Earth Planet. Interiors, 5, 61-76.

Haskell, N. A., 1962, Crustal Reflaction of Plane P and SV Waves, J. Geophys. Res., 67, $4751-4767$.

Honda, H., 1962, Earthquake Mechanism and Seismic Waves, Geophys. Notes, Tokyo Univ., $15,1-97$.

Isacks, B. L., L. R. Sykes and J. Oliver, 1967, Spatial and Temporal Clustering of Deep and Shallow Earthquakes in the Fiji-Tonga-Kermadec Region, Bull. Seism. Soc. Amer., 57, 935-958.

KanamoRI, H. and J. J. CiPar, 1974, Focal Process of the Great Chilean Earthquake May 22, 1960, Phys. Earth Planet. Interiors., 9, 128-136.

Kellher, J., L. Sykes and J. Oliver, 1973, Possible Criteria for Predicting Earthquake Locations and Their Application to Major Plate Boundaries of the Pacific and Caribbean, J. Geophys. Res., 78, 2547-2585.

KeYLIS-BOROK, V.I., 1959, On Estimate of the Displacement in an Earthquake Source and of Source Dimensions, Ann. Geophys., 12, 205-214.

Mıкumo, T., 1969, Long-Period P Waveforms and the Source Mechanism of Intermediate Earthquakes, J. Phys. Earth, 17, 169-192.

Mikumo, T., 1971, Source Process of Deep and Intermediate Earthquakes as Inferred from Long-Period $\mathrm{P}$ and $\mathrm{S}$ Waveforms 1. Intermediate-depth Earthquakes in the Southwest Pacific Region, J. Phys. Earth, 17, 169-192.

MoGI, K., 1968, Development of Aftershock Areas of Great Earthquakes, Bull. Earthq. Res. Inst., 46, 175-203. 
本谷義信, 1970,1969 年 8 月 12 日根室東方沖地震の余震活動, 北海道大学地球物理学研究報告, 24 , 93-106.

Orke, K., 1969, The Deep Earthquake of June 22, 1966 in Banda Sea: A Multiple Shock, Bull. Disaster Prevention Res. Inst., 19, 55-65.

OIKE, K., 1971. On the Nature of the Occurrence of Intermediate and Deep Earthquakes 3. Focal Medanisms of Multiplets, Bull. Disaster Prevention Res. Inst., 21, 153-178.

Wu, F. T. and H. KANAMORI, 1973. Source Mechanism of February 4, 1965, Rat Island Earthquake, J. Geophys. Res., 78, 6082-6092.

Wyss, and J. N. BRune, 1967, The Alaska Earthquake of 28 March 1964: A Complex Multiple Rupture, Bull. Seism. Soc. Amer., 57, 1017-1023. 